

\section{MESSAGE FROM THE CHAIRMAN}

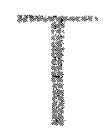

he year 1999 marked a milestone in SPACH's efforts to preserve Afghanistan's cultural heritage thanks in part to joint SPACH-UNESCO assessment missions carried out last summer. These were headed by professional experts in architecture and archaeology such as Andrea Bruno, Amund Sinding-Larsen and, last but not least, Arch. Prof. Maurizio Taddei, who passed away last February and whom all of us remember with profound regard and respect. In him we have lost a great and world-class orientalist, who served as chief of the Italian archaeological missions to both Afghanistan and Pakistan, organised by IsMEO (now IsIAO) for the last 50 years.

Among SPACH's 1999 achievements, I would like to recall:

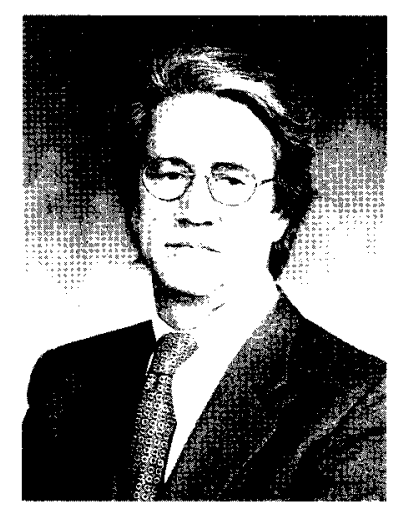

JAM MINARET: Construction of a wall to protect its base from erosion by the Jam River.

KABUL MUSEUM: Efforts are in progress to compile a complete inventory of the remaining objects.

MASJID-I-NO GUMBAD: The metal protective roof of this ancient mosque in Balkh has been repaired.

TILE WORKSHOP IN HERAT: Financial assistance has been provided for the continuation of this precious traditional workshop inside the most prominent mosque of Herat.

I would like to mention that even though 1999 has been most fruitful and a year of concrete activities by SPACH, the result is still very modest compared to the actual needs of the country. However, I feel encouraged by the positive efforts, considering the precarious political situation in Afghanistan and the financial capacity of SPACH, which is very limited indeed (an average income of US $\$ 50,000$ per annum provided by Cyprus, Greece, France, Italy, Netherlands, Norway, Portugal, UNESCO, NGOs and SPACH members).

Luckily, there are contributions in kind by people who put their time, knowledge and experience at SPACH's disposal. These are the members of SPACH's Executive Committee, FAO (which lent the office space for SPACH's coordinator and assistant in Islamabad) and, of course, the authorities in Afghanistan who facilitated the execution of the projects.

However, to prevent the cultural heritage of Afghanistan from dwindling into abandonment and destruction, it is crucial that further donors join hands with SPACH to give it the financial means to be more functional and effective in its humble efforts to preserve the cultural treasures of an impoverished country.

The UN General Assembly Resolution (A/RES/54/189A-B, paragraph 3O) of 14 February 2000, reads: "The cultural and historic relics and monuments of Afghanistan belong to the common heritage of mankind.... and requests all Member States to take appropriate measures...". I join this appeal which is reiterated every year, not only by the General Assembly, but also by Secretary-General Kofi Annan (paragraph 82, Report of 16 November 1999): "to protect cultural and historic relics and monuments of Afghanistan from acts of vandalism, damage and theft". I am sure that other donors will join SPACH's efforts to prevent the disappearance of the rich and invaluable cultural heritage of Afghanistan. 


\section{ABOUT SPACH}

\section{CONTENTS}

$\mathrm{T}$

he Society for the Preservation of Afghanistan's Cultural Heritage (SPACH) was established in 1994 in Islamabad, Pakistan, by a group of concerned individuals, in response to a growing awareness of the vulnerability of Afghan cultural heritage. Through its newsletters, lectures and media interviews, SPACH aims to disseminate information about the state of collections, historical monuments and archaeological sites in Afghanistan and to increase its international membership. Through advocacy within Afghanistan, SPACH pursues its efforts to limit destruction of this significant part of the world's cultural heritage. SPACH also supports projects to restore sites of historic importance and has been assisting the Ministry of Information and Culture in establishing an inventory of objects still in the possession of the National Museum in Kabul. SPACH is registered in Paris as an international NGO (Decret 1557, Journal Officiel n. 21).

Current members of SPACH Executive Committee:

Enrico De Maio, Chairperson Ambassador of Italy

Nancy H. Dupree,

Vice-Chairperson

Terence Barker, Treasurer

Jean-Yves Berthault

Dimitrios M. Loundras

Sadaaki Numata

Jaap A. Walkate

Tore Toreng

Christian Dunant

A. H. Dani

Erick de Mul

Brigitte Neubacher

Nora De Laet

SPACH Staff:

Robert Kluyver

Mirella Dummar Frahi

Ihsanullah Mamundzai
ACBAR/ARIC

Jam Minaret

Prof. Maurizio Taddei visits Ghazni

Biographical Note:

Prof. Maurizio Taddei

Masjid-i-No Gumbad

Tile Workshop in Herat

The Musallah Complex 10 in Herat

Kabul Museum Update

Mausoleum of

Timur Shah, Kabul

Conference/

Symposium Notes

Face of Large Bamiyan

Buddha Blackened

SPACH Library Series;

Kateeba

SPACH Donors; SPACH 16

Representative in Kabul

Decrees by Mullah Omar 17

Has Anyone Seen the

Ambassador of the Netherlands

Dipankara Bas Relief?

Ambassador of Norway

Ambassador of Switzerland

Membership Forms

Map of Afghanistan

Professor, Qaid-i-Azam

University

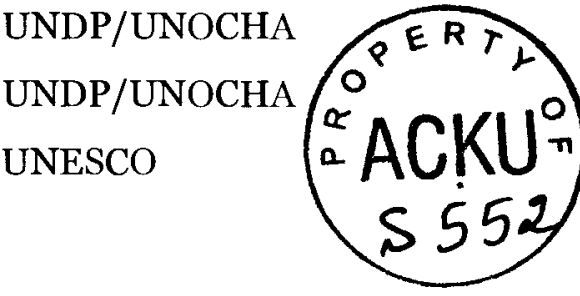

Representative in Afghanistan

Programme Coordinator

Administrative Assistant 


\section{JAM MINARET}

B eing one of the most spectacular monuments in Afghanistan and the second highest minaret in the world, the Jam Minaret has been on SPACH's agenda for several years. It is in a vulnerable state. Not only is the minaret leaning, but also illegal excavations at its base have been reported. SPACH was requested by the Ministry of Information and Culture in Kabul to assist in protecting it.

Jam Minaret dates back to the $12^{\text {th }}$ century and rises some 65 metres from an octagonal base some 16 metres in diameter. A double-spiral staircase is inside the tower. The facade is richly decorated with turquoise brick reliefs and an epigraphic band with the $19^{\text {th }}$ Sura of the Koran (see back cover). Scholars continue to speculate whether the minaret was part of a mosque or whether it was built to proclaim the victory of Islam.

Access to the minaret, which is located in Ghor Province in a remote valley surrounded by barren mountains, has proven frustrating and difficult.

In 1995, Dr A W Najimi visited Jam and recommended to SPACH that a gabion wall should be built to protect it from flooding and erosion by the two rivers, Jamrud and Harirud. Attempts to send further missions in 1998 failed. In August 1999, the Italian architect, Prof. Andrea Bruno, an Afghan hydrologist, Eng. Akbari, and officials from the Monuments Department in Herat succeeded in reaching Jam, protected by assurances for a brief cease-fire during their visit.

Before 1979, Jam had been visited and studied by a number of Afghan and international experts. Prof. Andrea Bruno was about to start a UNESCOsupported restoration project in 1979 - the bridge across Harirud had been built, a building for the workers was ready, the gabion wires had been delivered - when the war broke out and all work had to be abruptly stopped. In summer 1999, Andrea Bruno found the stones for the planned gabion wall still piled up - the gabion wire was gone, the building and the bridge had collapsed.

As a result of his visit, Andrea Bruno recommended to SPACH that it should build a protective wall as soon as possible - during the winter months before the arrival of the spring floods.

Eng. Akbari subcontracted $\mathrm{Mr}$ Gul Agha, who has his roots in Ghor Province and runs the NGO Payam-i-Ghor, to carry out the project of building a wall along the Jam River.

Various factors combined to make working conditions difficult: the minaret being on a frontline, the onset of an early winter and the isolation of the site. However, the protective wall was built, using stones and supporting wooden beams. Work was completed in early February 200o. The Herat Department of Monuments has committed itself to placing guards near the site and to stop illegal excavations.

SPACH is planning to send a mission this summer to assess the impact of this protective wall and will then decide whether further work is needed.

This project represents a benchmark in preserving Afghanistan's cultural heritage. It has also boosted the morale of the local community who expressed their joy by dancing around the minaret upon completion of the wall.

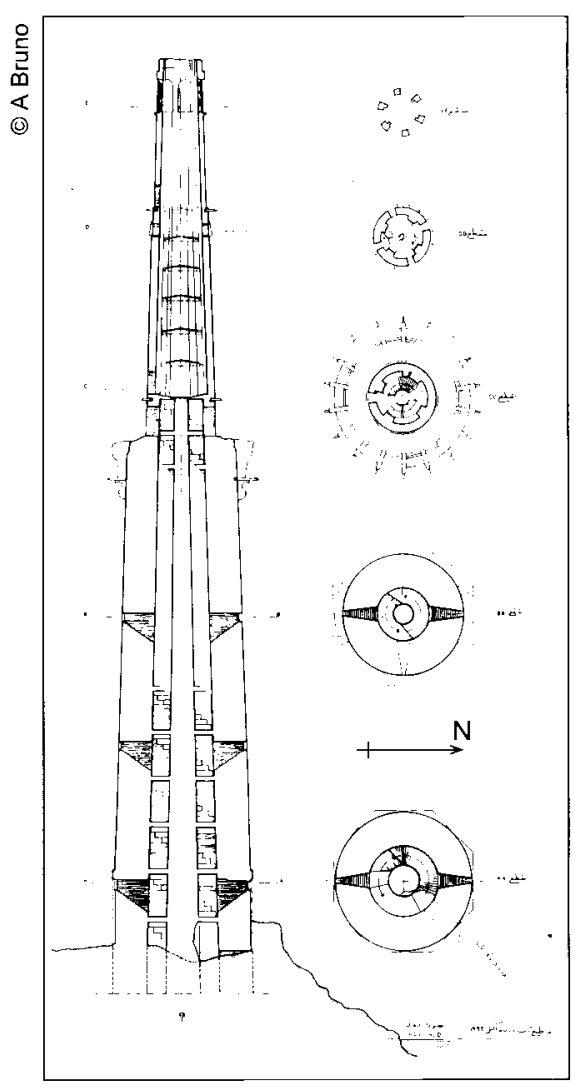

Above: The vertical section of Jam Minaret and some horizontal sections. 


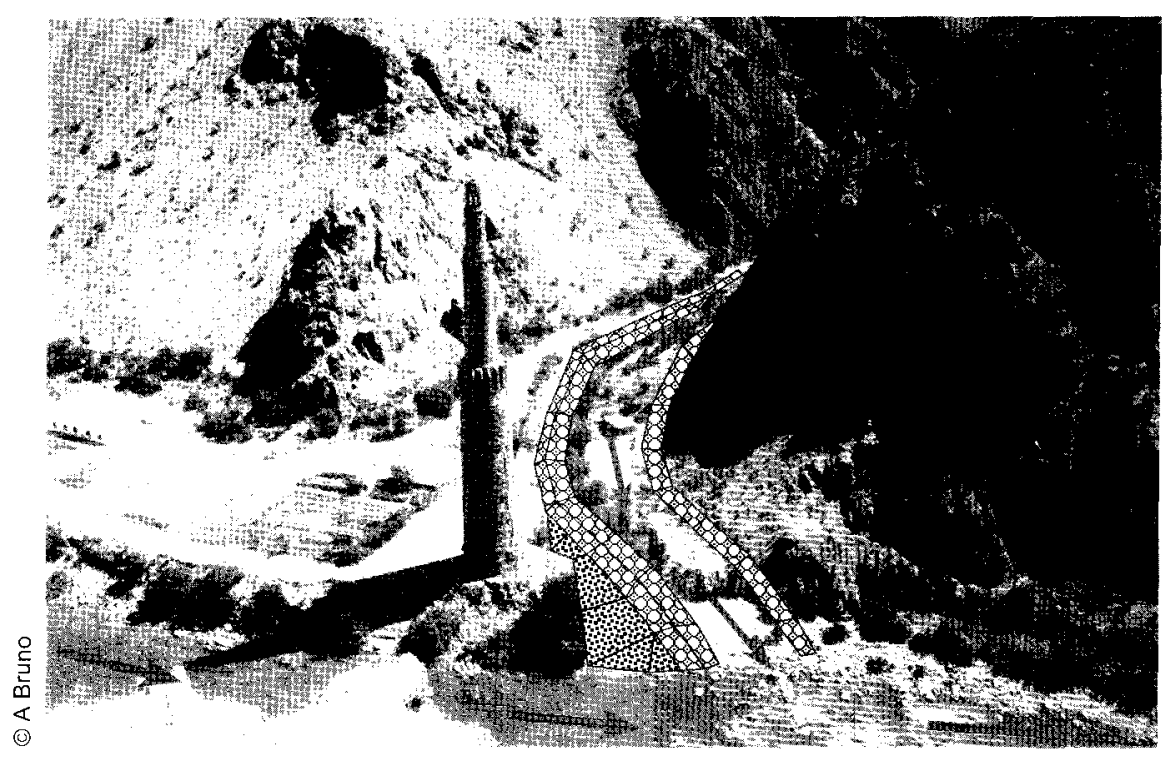

Left: Plan by architect Andrea Bruno to protect the base of the minaret.

Below: Base of the minaret as it was on 3rd August 1999.

Bottom: Protective wall constructed in February 2000.
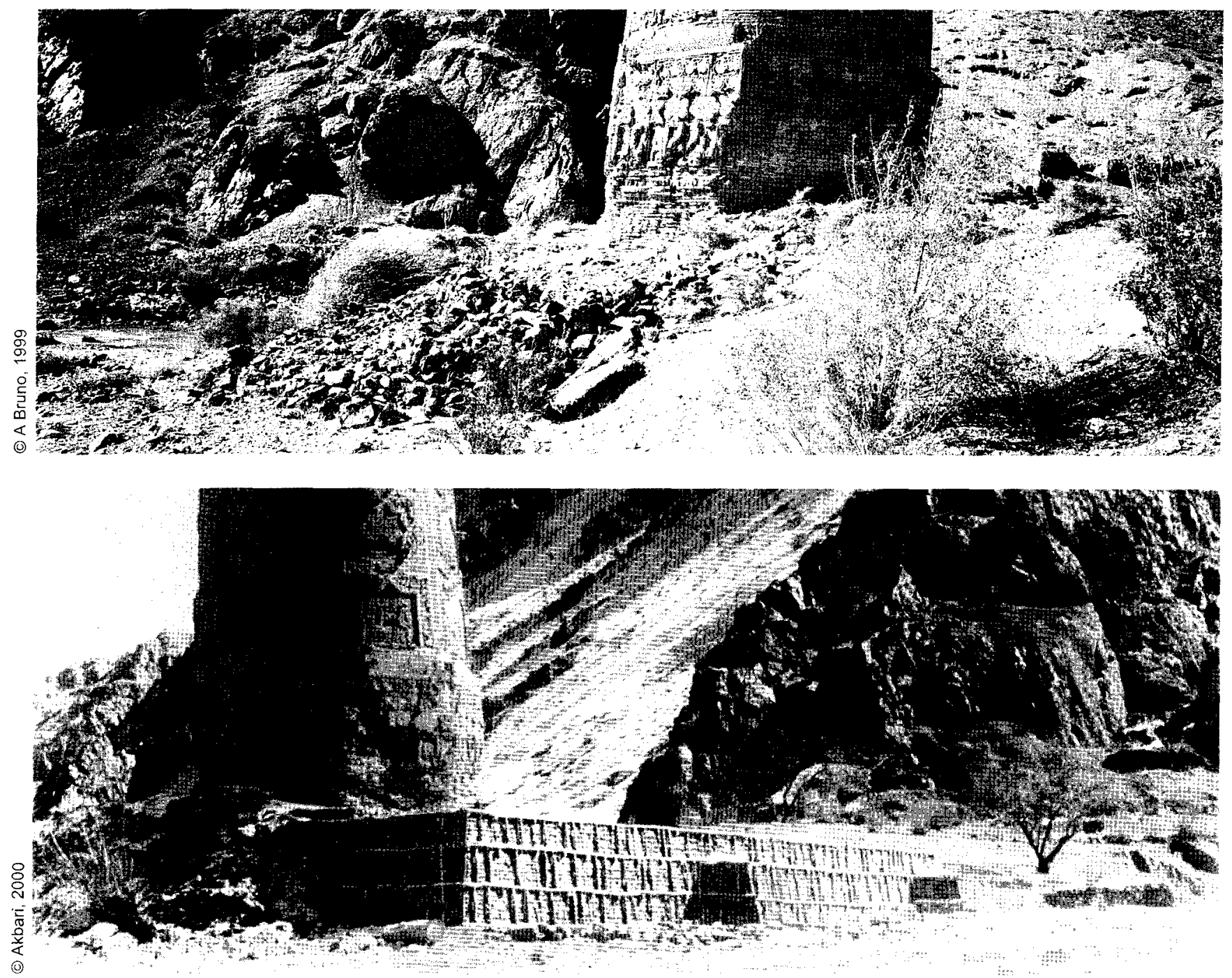


\section{PROF. MAURIZIO TADDEI VISITS GHAZNI}

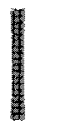

n October 1999, Prof. Maurizio Taddei kindly agreed to undertake, on behalf of SPACH, a factfinding mission to Ghazni, where he carried out extensive excavations before 1978 . His findings were devastating and sad an extract of his report follows:

\section{The Italian Excavations at Ghazni: Their Present State}

Some of the protection put in place by the Italian

Archaeological Mission in the years before 1978 is still there. We owe it to them that not everything is lost. Unfortunately some of the protection has been removed, which has caused severe damage to the ancient remains.

At Tapa Sardar I could not see all the monuments, as some of them are still protected by roofs. In any case, I could ascertain the following main damage and losses:

1 Chapel no. 23 is empty. Both the pedestal of Durgâ (including the buffalo) and that of the bejewelled Buddha have been destroyed: no traces of them remain.

2 The remains of the Buddha in chapel no. 17 have been destroyed.

3 The two nâgas in chapel no. 37 have been destroyed (or removed?). But the roofs of the three chapels have survived.

4 The unbaked-clay stûpas and thrones nos. 24, 19, 38, 42 have almost completely disappeared, as the roofing and other protection were removed.

5 The main stûpa and the minor stone stûpas 21, 20, and 11 have been damaged, though they are still standing.

6 Chapels no. 41 and no. 75 are still protected by roofs. I could ascertain that the stûpa in chapel no. 75 is still there, though somewhat decayed; the Buddha image no. 85 in the same chapel has been destroyed.

7 Room no. 36 has been almost destroyed.

8 The worst damage is noticeable in the row of unbaked-clay stûpas and thrones on the back of the main stûpa (nos. 1 to 10). The large roofing which protected both the unbaked-clay artefacts and the rear

Right: Maurizio Taddei, Andrea Bruno and Afghan staff at the Minaret of Massud III in Ghazni. side of the main stûpa has been completely removed. The natural consequence has been the decay of the remains, due to rain and snowfall. It is to be remembered that most of the unbaked-clay artefacts at Tapa Sardar had been treated with Paraloid, which

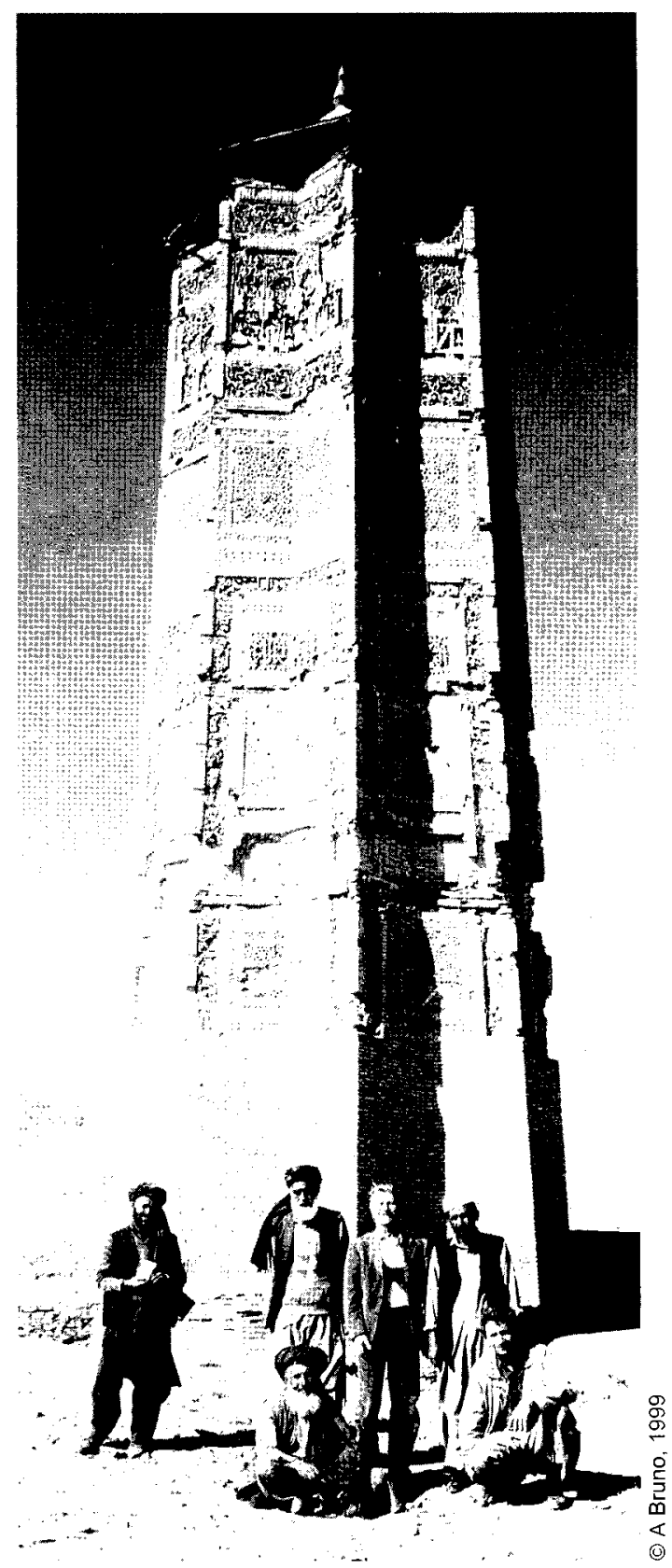


is a very effective protection from decay (crumbling, etc.), provided the treated artefacts are not exposed to direct contact with water.

9 The Parinirvâna chapel is fairly well preserved, though whatever remained of the Buddha's head has been intentionally destroyed.

10 The area around stûpa no. 64 is badly damaged, but the right foot of the Buddha in chapel no. 100 survives - surprisingly the traces of the painting on mud plaster behind it are still visible. I could not ascertain whether anything survives of the "fortification" no. 69. Nor could I ascertain whether the inscription on the mudplaster floor between 64 and 69 has been at least partially preserved.

11 The area round chapel no. 87 (the "fire-altar") is very badly decayed. The "fire-altar" itself appears to have been razed.
The Palace of Massud III has been almost completely deprived of the pieces of epigraphic decoration, which were kept in situ. The mosque appears to have been pillaged: one of the marble bases, broken, is still lying there. I was told that some pieces were taken to the museum in the Shahr-e Nau: and I have actually seen there one of the marble bases from the mosque. Many other marble pieces from the paving have been stolen.

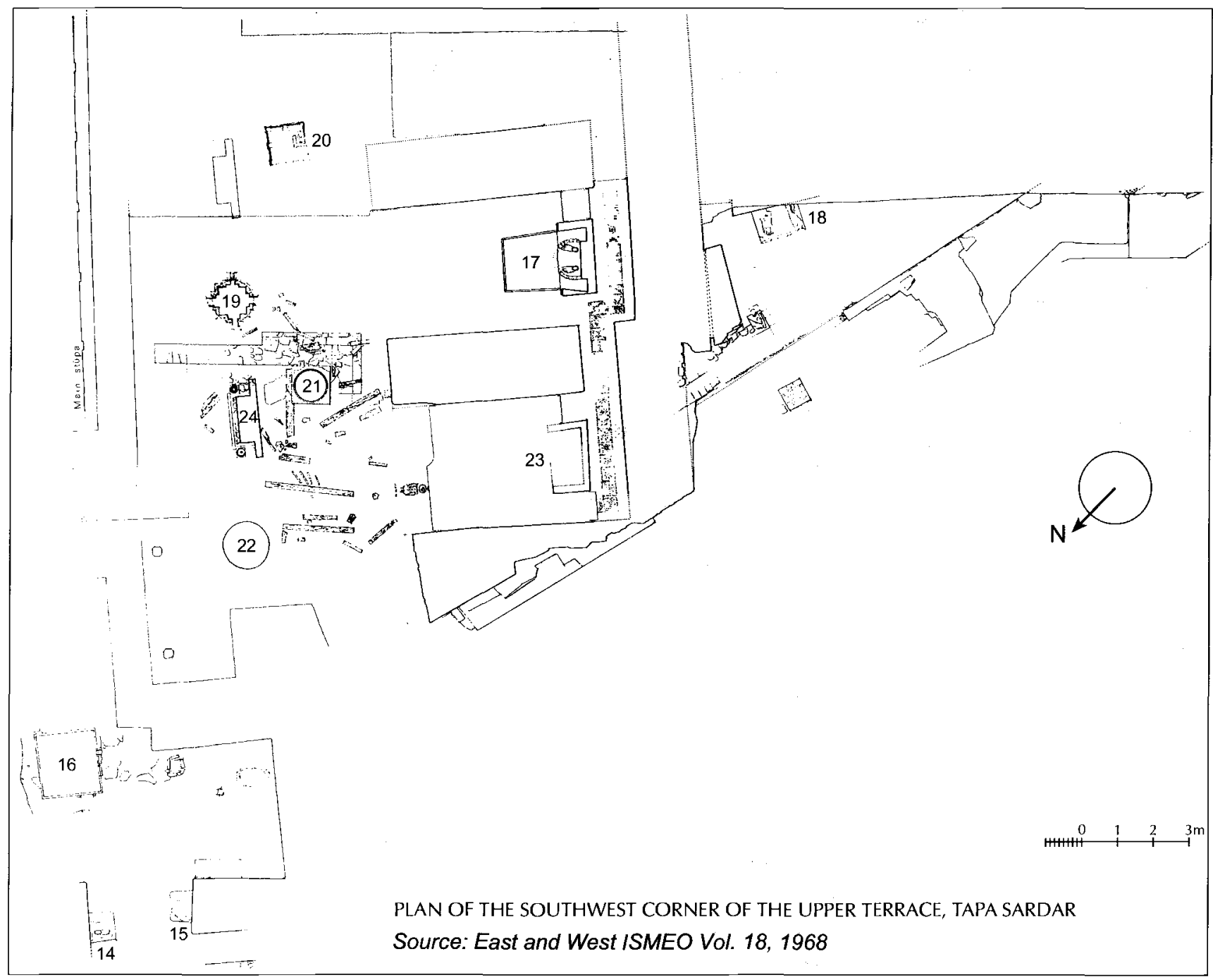

5 
The walls are in a state of decay, though on the whole the various structures are still standing.

The mud-brick and pakhsa walls at Tapa Sardar and in the Palace of Sultan Massud have suffered from the effects of the weather. Nevertheless most of them are not lost, though they are in danger. The decay of such structures, whenever there is no proper maintenance, is slow at the beginning, faster and faster as soon as the rain (and snow) water has found its way into the core of the masonry. This is why the intervention needed (see below) is on minor scale, but urgent.

The store-house of the Italian Archaeological Mission, close to the Palace of Sultan Massud, has been razed to the ground. The most important objects were taken to Kabul. The shards and other minor objects (of no commercial value) are still kept in their cases in the museum in the Shahr-e-Nau.

\section{Recommendations}

Both at Tapa Sardar and in the Palace of Sultan Massud, we have now to face problems of maintenance and salvaging rather than of restoration.

I suggest the following course of action:

1 Filling up with sand the space between the rear wall of the main stûpa at Tapa Sardar and the mud-brick wall behind the stûpa itself, in order to protect what remains of the row of unbaked-clay stûpas and thrones $(25 \times 3.5 \times 1.5 \mathrm{~m}=$ ca. 131 cubic $m$ ). This is the only feasible way of preserving whatever is left for future restoration and research. Sand can be obtained from the riverbed and brought to the foot of Tapa Sardar by truck, then higher up on donkeys.

2 Repairing the roofs and other protection (wooden planks, mats, etc.) in other parts of Tapa Sardar and the Palace of Sultan Massud III.

Maurizio Taddei

November 1999

Preparations are
underway to implement
some of Prof. Taddei's
recommendations
during 2000.

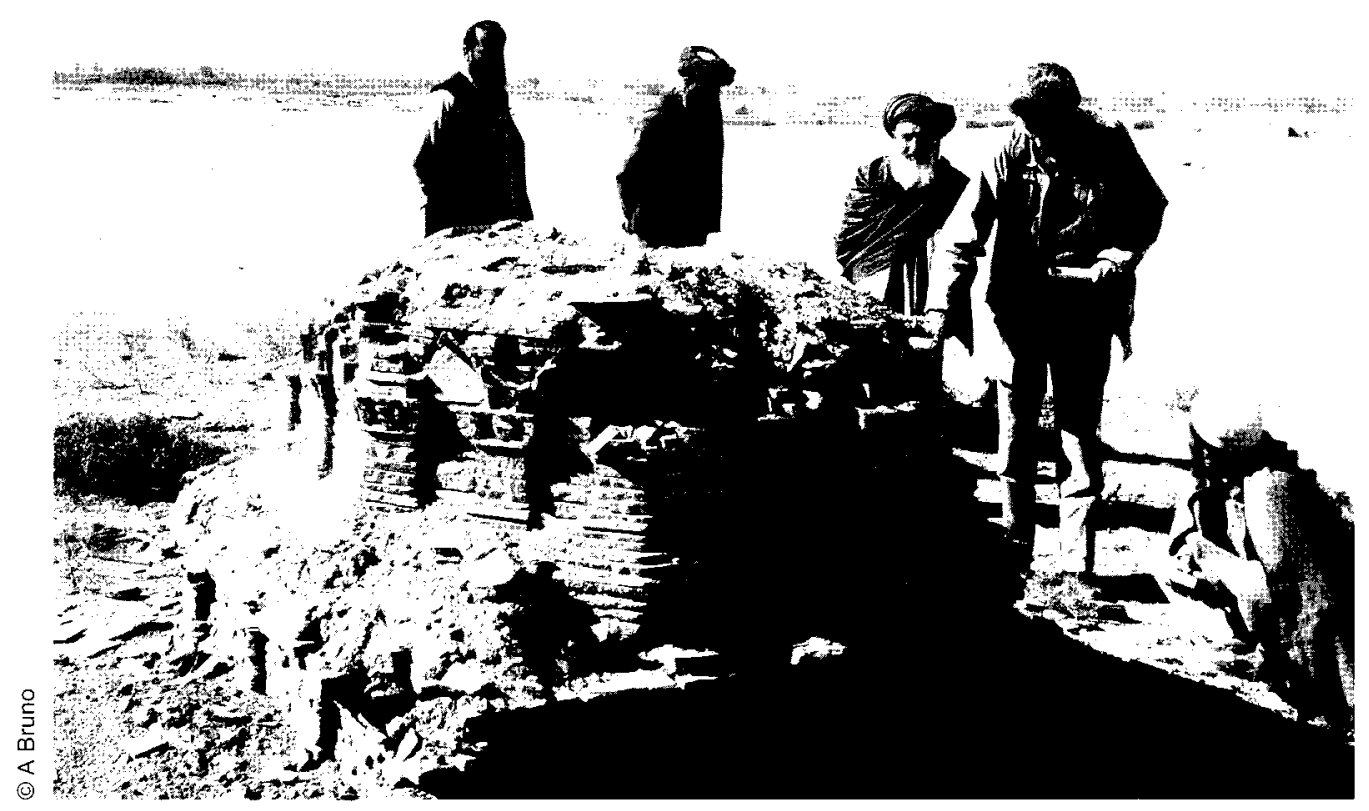

Left: Maurizio Taddei assessing the poor condition of a stupa in Tapa Sardar. 


\section{BIOGRAPHICAL NOTE: PROF. MAURIZIO TADDEI}

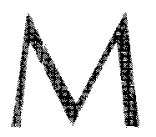

aurizio

Taddei was

born in

Rome in 1936. In 1961

he achieved "Laurea"

in Archaeology at the

University of Rome

"La Sapienza".

In 1964 he won the government competition to become inspector of the National Museum of Oriental Art in Rome.

From 1968 he was professor of archaeology and history at the Oriental University Institute of Naples, initially as director of the Department of Asian Study and between 1981 and 1984 as "Rettore".

From 1986 to 1995 he was a member of the executive committee of the Italian Institute for the Middle and Extreme East

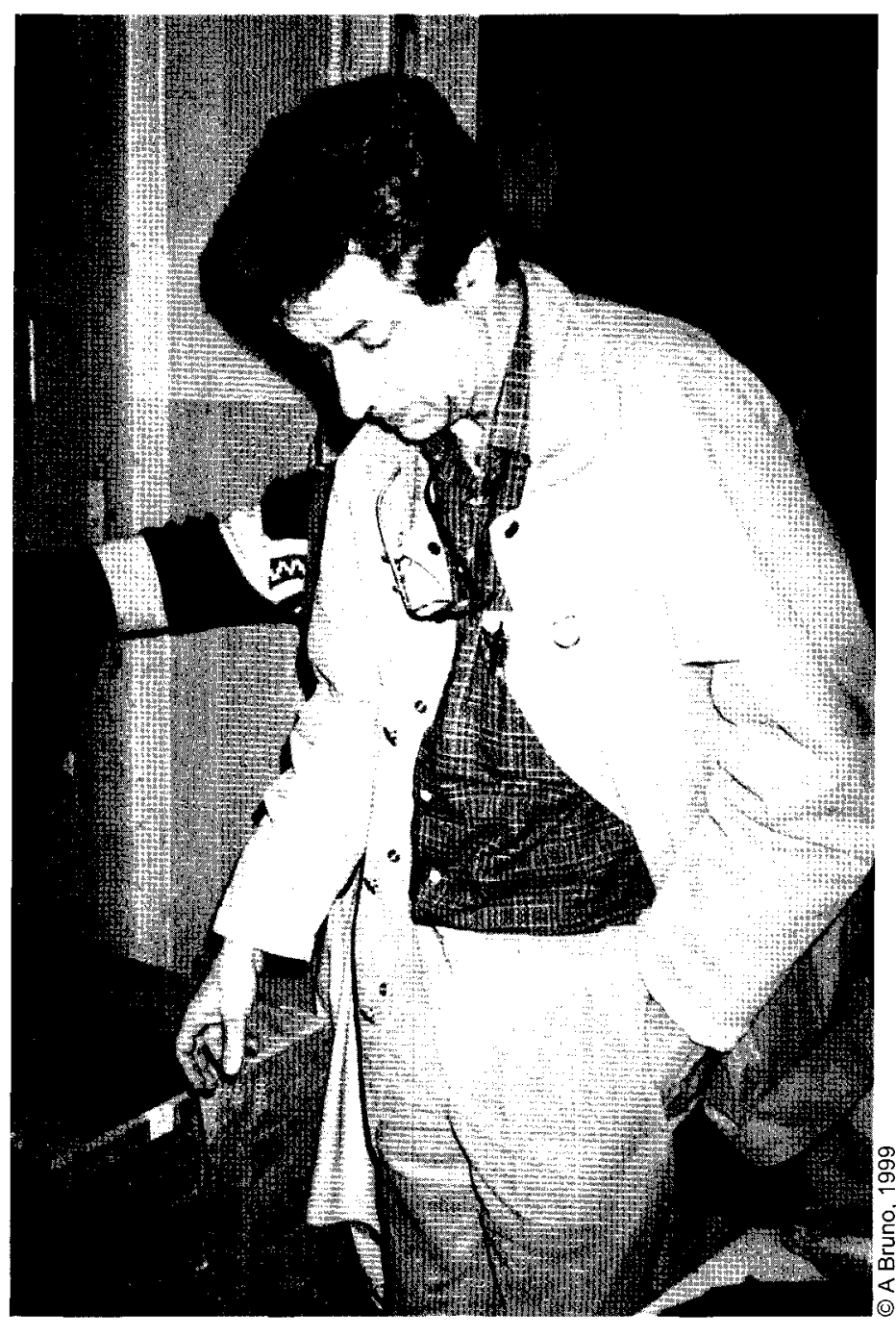

(IsMEO), now the Italian Institute for Africa and the East (IsIAO).

From 1996 he was a member of the scientific committee of the IsIAO.

Maurizio Taddei started his career as an archaeologist in the early 6os, under the guidance of Giuseppe Tucci, the renowned expert of oriental art. He was director of the Italian archaeological mission in Pakistan, and in Afghanistan. We owe to him the excavation of the Buddhist sanctuary in Tapa Sardar, near the city of Ghazni. For many years he was the editor of the specialised magazine "East and West" and the Italian representative Above: Maurizio Taddei visiting the depots of Kabul Museum. to the international association "South Asian Archaeology".

SPACH was profoundly grieved by Prof. Maurizio Taddei's sudden death in early February 2000.

His contribution to the research of Afghanistan's heritage has been invaluable.

Prof. Taddei's dedication to Afghanistan will remain an inspiration to all of us. 


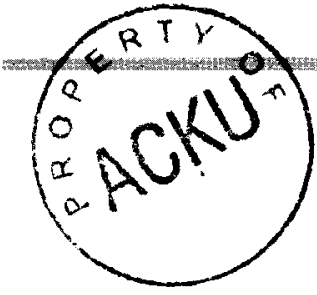

$\mathrm{B}$ eing the earliest Islamic monument in Afghanistan, built during the $9^{\text {th }}$ century AD Masjid-i-No Gumbad is a unique example of this early period. "No Gumbad" means nine domes.

The original nine domes have fallen and the floor is now buried under rubble covering the lower half of the columns. Serious deterioration of the stucco decoration on the capitals, ranging from geometric to abstract floral designs, has occurred.

The protective roof had again lost some of its metal sheets.

During 1999, SPACH contacted Eng. Sharif from the Monuments

\section{MASJID-I-NO GUMBAD, BALKH}

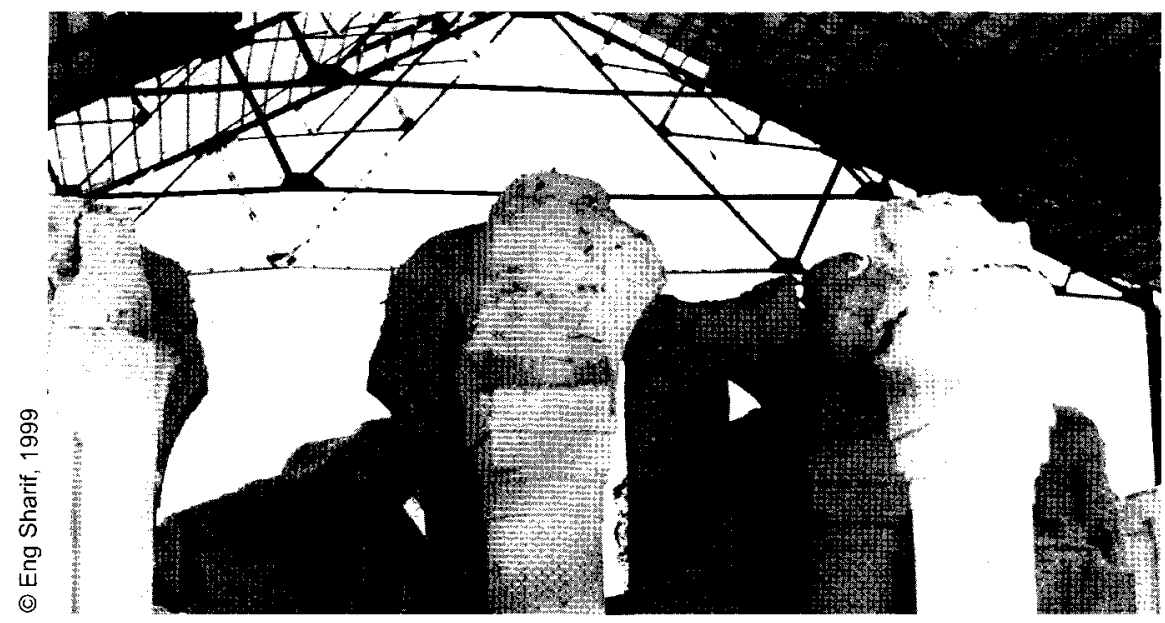
Department in Mazar-i-Sharif who supervised local craftsmen during the repair of the protective metal roof over the mosque. The work was completed earlier this year and the roof will continue to guard the fragile structure against the rain.

The strong winds that blow across the plain of Balkh continue however to threaten both the mosque and its roofing, and an urgent intervention is required to set up a more comprehensive protection. Moreover the site deserves a complete survey led by an international expert, as it could reveal valuable historical and architectural information.

Top: Metal roof before repair. Above Right and Right: Repaired metal roof.
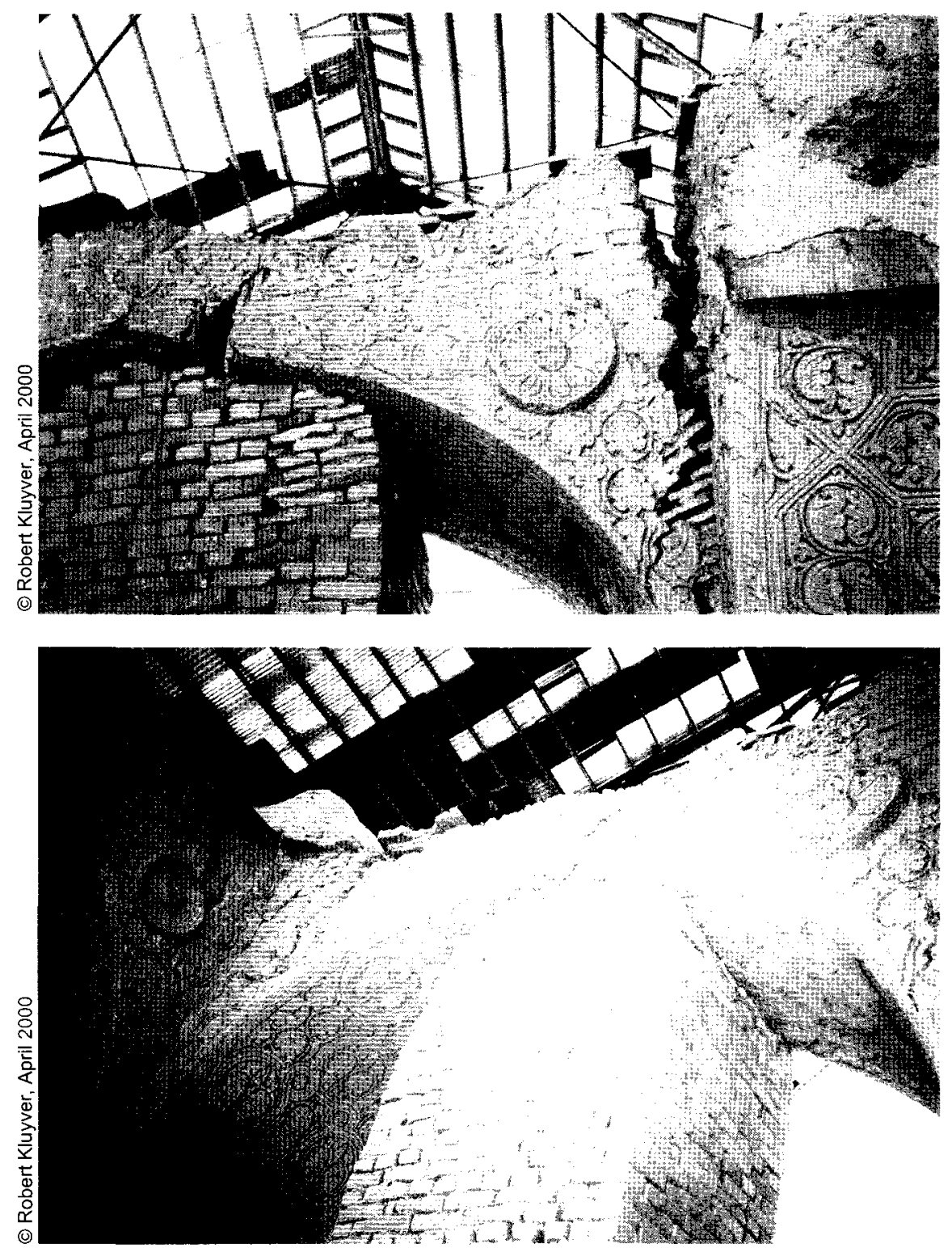


\section{TILE WORKSHOP AT MASJID-I-JAMI, HERAT}

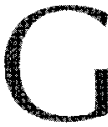
oing back more than 1000 years, Masjidi-Jami (Friday Mosque) in Herat vividly reflects Afghanistan's turbulent history. It has survived numerous ill-fated attacks: destroyed by fire and rebuilt in the year 1200; repaired after damage by Mongol raids; and again it suffered extensive damage in the $16^{\text {th }}$ century. An ambitious restoration programme begun in 1943 continues to date. The mosque remains the centre of Herat and daily attracts worshippers.

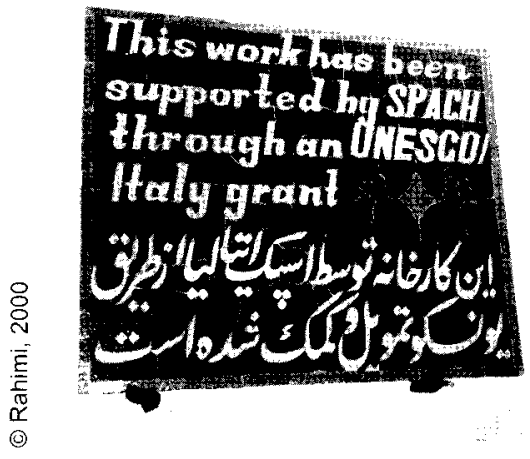

Following SPACH's visit to Herat in July 1999, it was decided to give financial support to the tile workshop in the back of Masjidi-Jami.

About a dozen craftsmen and young apprentices are using ancient and time-consuming techniques going back to the $15^{\text {th }}$ century. After making the design of floral patterns and calligraphy on paper, pieces of coloured tiles are carved, filed and assembled into panels which are held together by a layer of cement.
The colours include three shades of blue, orange, yellow, red, green lilac, black and white. The workshop's main task is to repair and maintain the exquisite mosaic surfaces of Masjid-i-Jami, which luckily were hardly damaged during the recent war. SPACH'ssupport has allowed the hiring of additional craftsmen and the training of new apprentices who also receive literacy training.

The spectacularly huge bronze cauldron, created in 1375 and covered with verses from the Koran and verses from Sa'adi, the $13^{\text {th }}$ century Persian poet, has been enclosed by the authorities in a glass house in an alcove of the mosque's courtyard. The cauldron continues to receive donations for the upkeep of the mosque.
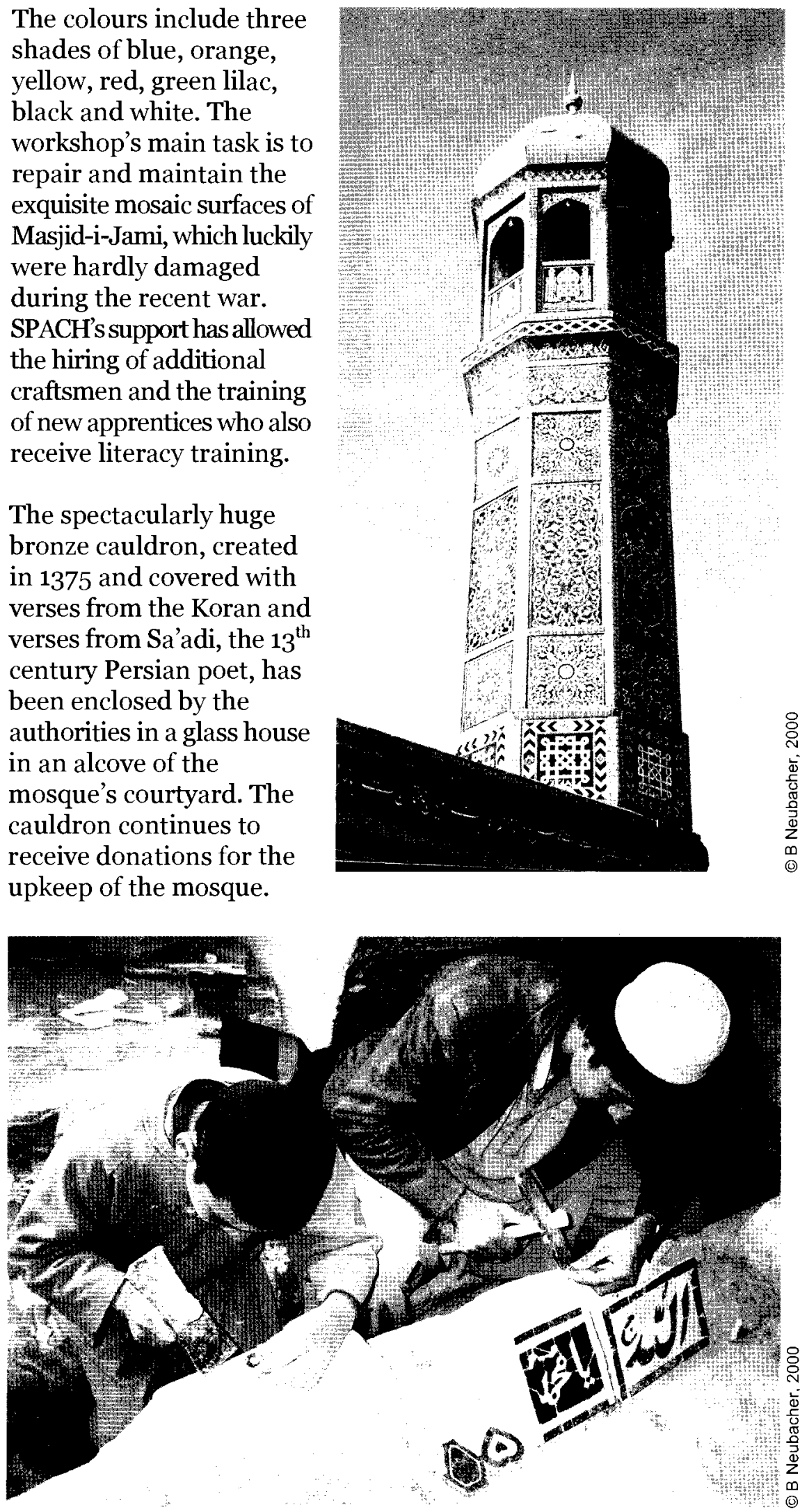


\section{MUSALLAH COMPLEX, HERAT}

7 he city of Herat, the second biggest in Afghanistan, has always occupied a strategic position in the region and has been at the crossroads for trade with Persia, India and China. The Musallah Complex was built in the $15^{\text {th }}$ century under the patronage of the Timurid Queen Gawhar Shad and by Sultan Hussain Baiqara. It includes the Sultan Hussain-i-Baiqara Madrassa with four minarets, the Mausoleum of Gawhar Shad with only one minaret left and the Mausoleum of Mir Ali Sher Nawai.

In summer 1999, a joint UNESCO-SPACH team visited Herat and its monuments, which have suffered tremendously in the course of Herat's stormy history. The Musallah Complex was considered top priority for any international intervention.

Of great concern have been heavy trucks, causing dangerous vibrations, that are using a widened road leading through the Musallah Complex and past the four minarets. Encouraged by SPACH, Herat's Department of Monuments recently built a metal gate which is stopping large trucks from using that route.

Essential repair work of the damage created by bullets and shells on the minarets of Sultan Hussain-i-Baiqara Madrassa will be carried out by SPACH in the next months. Plans are also

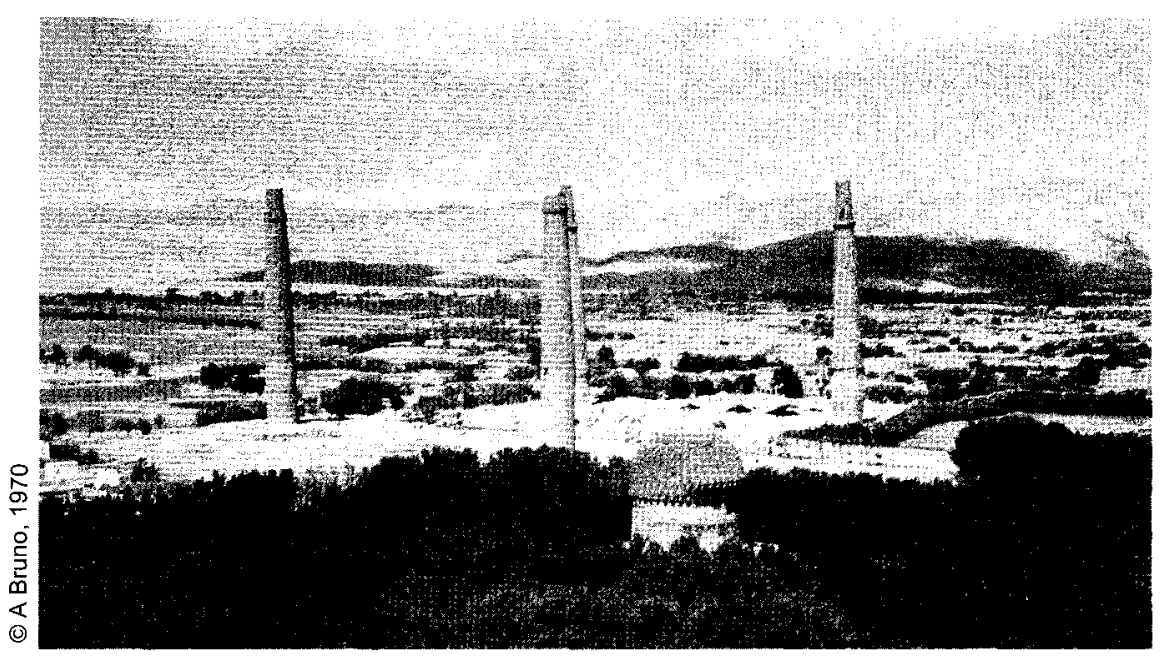

made to undertake other consolidation work such as the construction of a wall around the four minarets with a view to preventing all traffic from driving through this archaeological site and stopping encroachment by shopkeepers. Another wall is needed around the Mausoleum of Gawhar Shad in an effort to recreate the park. It is, also, hoped to replant the trees which used to protect the site from the infamous 120-days winds and to restore the "women's park" for the citizens of Herat. Efforts will be made to enlist the authorities, aid agencies and especially the community to contribute to the sustainability of the project.

The only minaret left near the Gawhar Shad Mausoleum is dangerously leaning, as its base is crumbling. It also has a large hole due to a rocket attack.

Because of the risk of its imminent collapse, international experts will be consulted on how to support the structure without causing further damage. More funds will also be needed for this intervention.

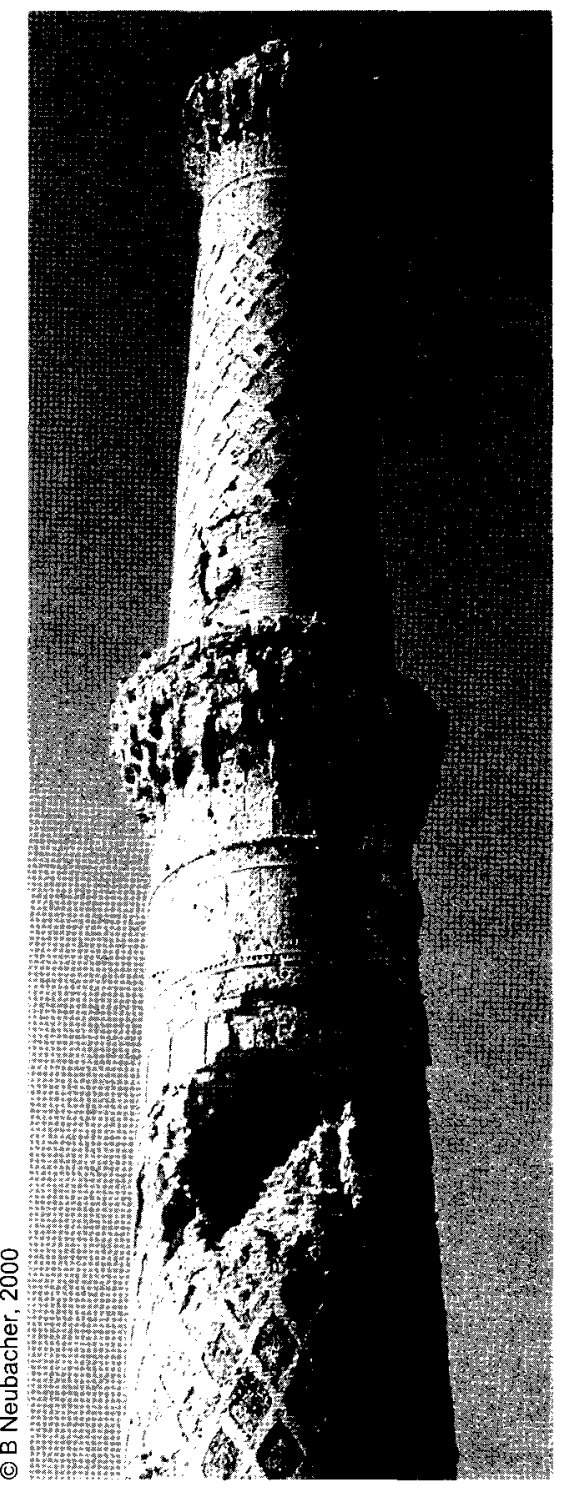




\section{KABUL MUSEUM UPDATE}

S

PACH continues its

financial support to the

Ministry of Information

and Culture in its efforts to clean

up storerooms and to document and pack the artefacts in the Kabul Museum. Ms Carla

Grissmann, for the fifth summer in a row, spent some six months in Kabul during 1999 and pursued her task of compiling the inventory of the remaining collection.

In January 2000, Deputy Minister Hotaki informed SPACH that the inventory was nearing completion and that it was planned to launch an international campaign in an effort to recover missing objects. SPACH will continue its assistance and it is hoped to finalise the inventory during 2000.

Chemicals and staff training in conservation of the artefacts will also be provided. More funds are needed for this ongoing project.

The Ministry of Information and Culture is continuing with the structural rehabilitation of the museum building in Darulaman. Considerable progress has been made - as most bullet holes are gone! However much work remains to be done if the building is to serve as a museum again.

Top and Right: Repaired facade of the Kabul Museum.
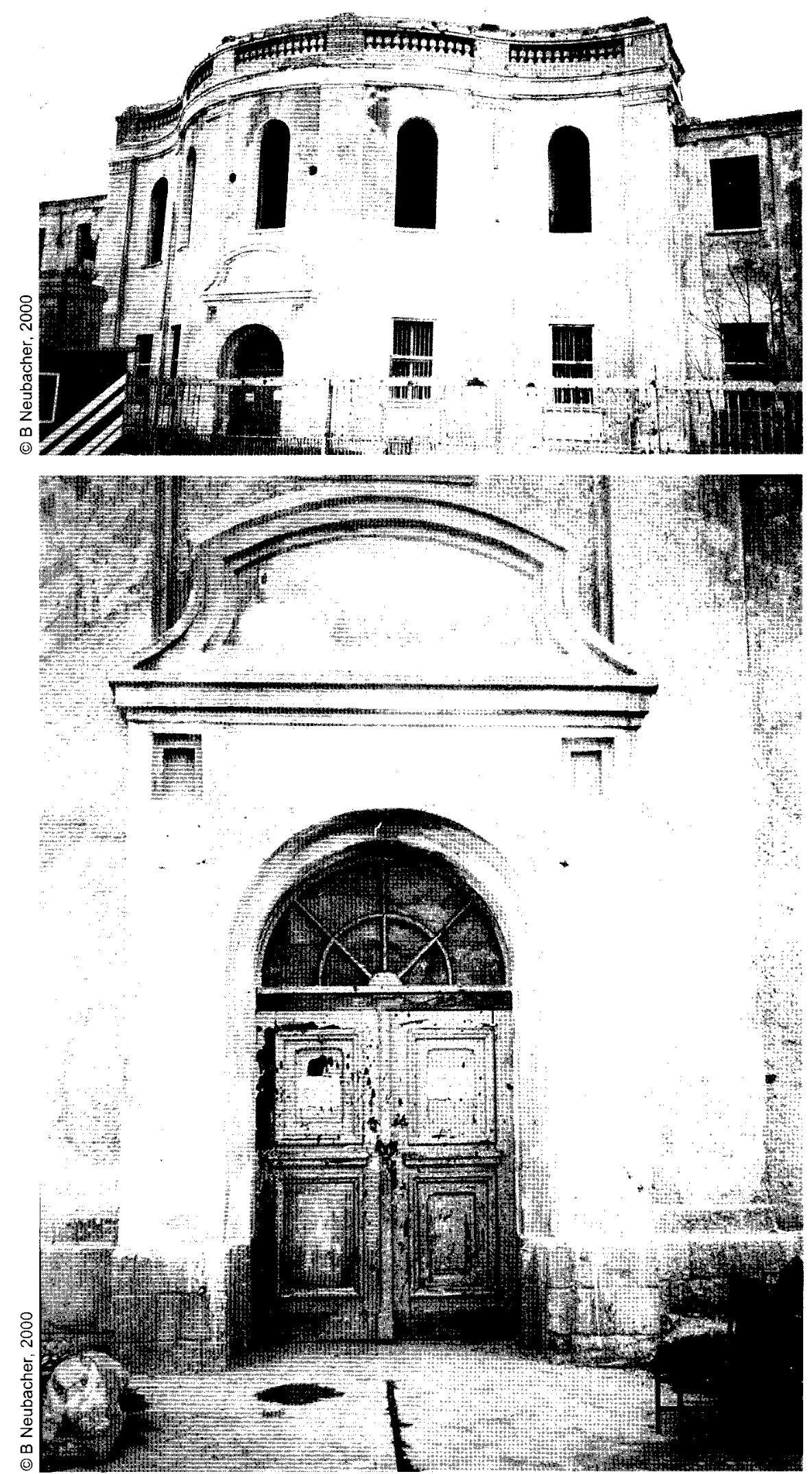


\section{MAUSOLEUM OF TIMUR SHAH, KABUL}

\section{T imor Shah (1772-1793), son of Ahmad Shah Baba, the second ruler of the Abdali dynasty, moved his capital from \\ Kandahar to Kabul, where he died in 1793 . He was buried in Charbagh, the present site of the mausoleum. When his son came to power, he ordered that a maus- oleum be erected over the tomb of his father. The struc- ture that exists today was not completed at the time.}

The mausoleum is a massive octagonal brick building, indicating strong Timurid influence. The structure is organised in three distinct levels: the first comprises an undercroft (containing the tomb of Timor
Shah) located in the brick and stone foundations. Above this, the second level comprises a square multi-height space bounded by massive brick supporting walls pierced with holes, forming an octagon to the outside. The third level comprises an octagonal drum, supporting a ribbed brick inner dome and an almost hemispherical outer brick dome.

The mausoleum used to be surrounded by a park, but the area is now filled with containers inhabited by tailors' shops. In early 1999, SPACH commissioned the Association for the Preservation of Historical and Cultural Heritage of Afghanistan (APHCHA), based in Kabul and headed by
Mr Mir Ahmad Joyenda, to carry out a technical survey of the mausoleum. During July 1999, SPACH also asked Arch. Prof. Amund Sinding-Larsen, VicePresident (Norway) of ICOMOS (International Council of Monuments and Sites), to meet the members of APHCHA in Kabul and assist them with and advise them on their technical survey.

Discussions are ongoing on how to proceed with the preservation of the mausoleum, including dealing with cracks that have appeared in the dome. A budget has been submitted to SPACH for its consideration. At present SPACH does not have the required funds, but hopes to address the rehabilitation of the monument at a later stage.

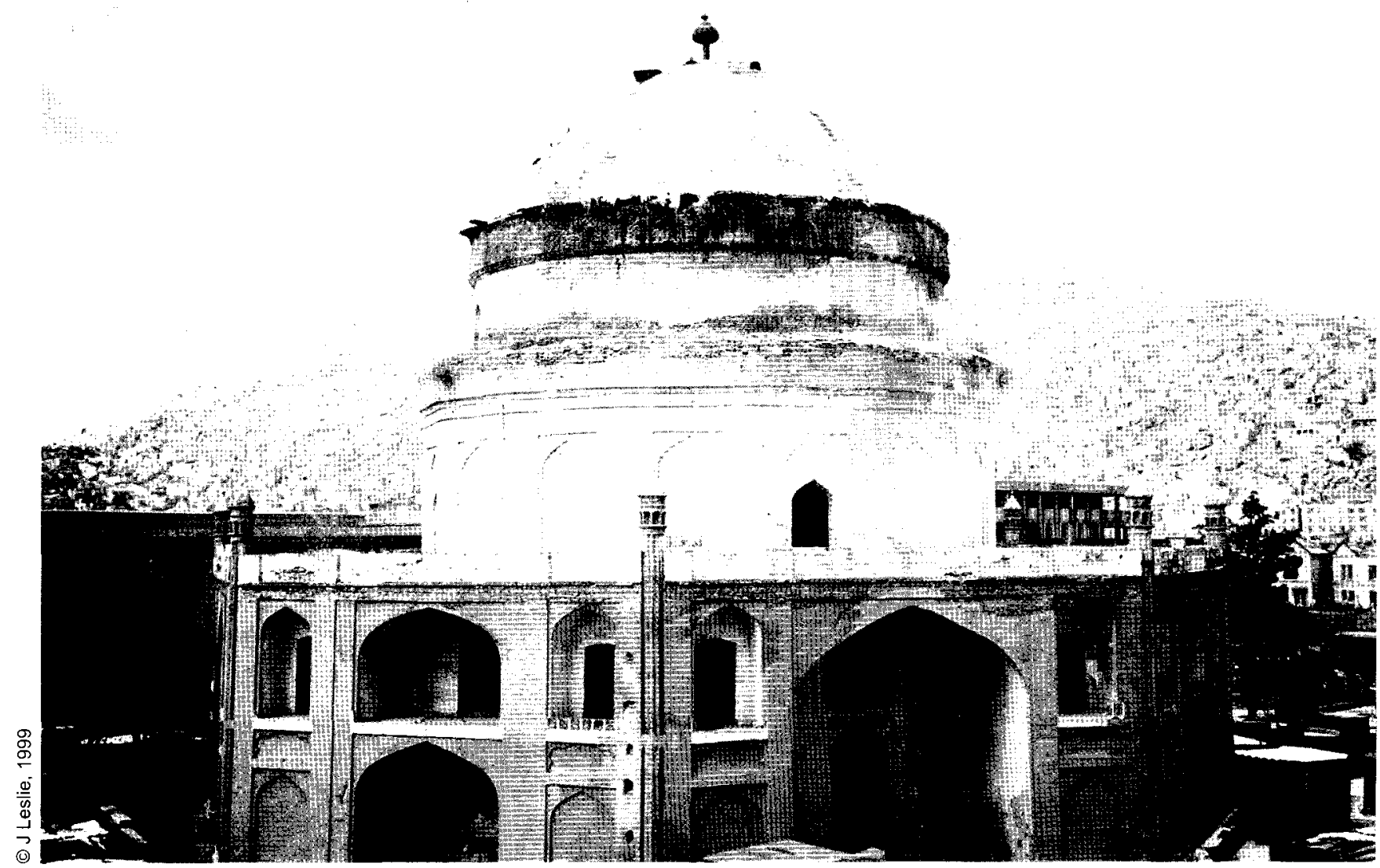




\section{CONFERENCE ON CONSERVATION AND MANAGEMENT OF THE BUILT HERITAGE \\ Lahore, Pakistan, January 2000}

$A$ fascinating conference was hosted by the Government of Pakistan in Lahore, bringing together conservation specialists from Turkey, Sri Lanka, Italy, India, France, Germany, USA and Pakistan.

A wide variety of topics was discussed:

conceptual issues and history; heritage management and planning education and training; historical and aesthetic investigations documentation structural and laboratory investigations and analyses site issues - the monument in its setting the conservation of a city - the conservation of a living phenomenon methodology and practice.

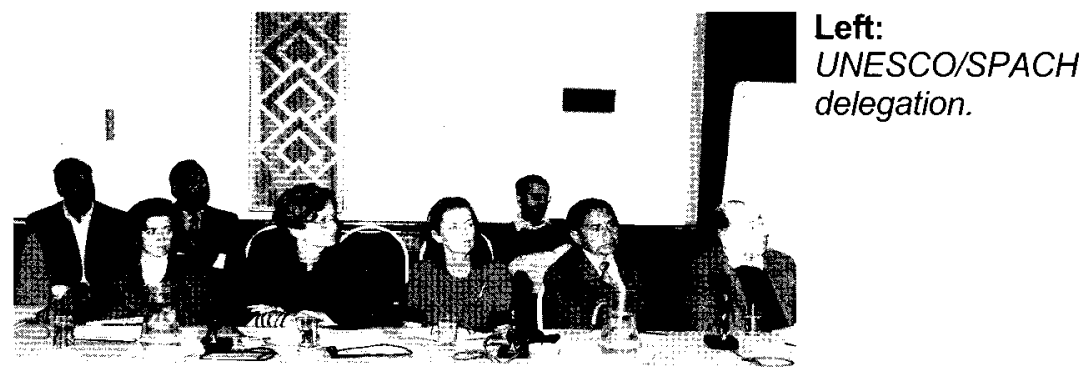

The conference concluded by adopting a declaration and recommend-ations relating to the heritage of Pakistan:

$\rightarrow \quad$ to create legal and necessary educational tools

* to create local, provincial and national inventories

* to examine and update legislation

* to impart conservation education at institutions of higher learning

* to establish project-related training programmes

\section{PROSPECTIVE REVIEW OF THE HISTORY AND ARCHAEOLOGY OF AFGHANISTAN - FROM GLORY TO PLUNDER Symposium at Pacific Asia Museum, Pasadena, CA, October 1999}

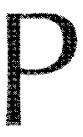

rof. Dr Alef-Shah Zadran, former Professor of Archaeology and Anthropology at Kabul University, represented SPACH at this symposium, organised by the International Committee for the Cultural Heritage of Afghanistan and the Pacific Asia Museum in Pasadena.
The symposium brought together internationally recognised scholars who conducted research and excavations in Afghanistan. Papers presented covered subjects ranging from the Kushans to the Islamic period, including numismatics. Discussions urged protection of sites under the current unsettled times. A resolution called for international support for these efforts.

For more information, please contact Mrs Mehria Mustamandy, International Committee for the Cultural Heritage of Afghanistan: tel. (818) 529-0787; e-mail: mustamandy@aol.com. 


\section{HEAD OF LARGE BAMIYAN BUDDHA BLACKENED}

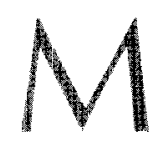

ore vandalism in Bamiyan! Already in 1997, a local

commander had caused an international outcry and protest when he had threatened to blow up the Buddhas in Bamiyan. In 1998, some of his threats became reality: the small Buddha was attacked not only by mortars hitting its groin and ripping away folds and part of the sleeve, but explosives seriously damaged its head and the frescoes in the niche above (see SPACH NewsLetter 5, page 21). SPACH protested to the Afghan authorities and received assurances that the Buddhas would be protected in the future.

However, in late 1999, the same commander was stopped at the last minute by the local Governor from committing yet another despicable and criminal act, as explosives had already been placed behind the large Buddha's head to cause massive damage. The head survived this threat, but has been blackened after two burning tyres were placed on the chin in the course of the last few months. Reports have been received that the commander has been arrested in the meantime.
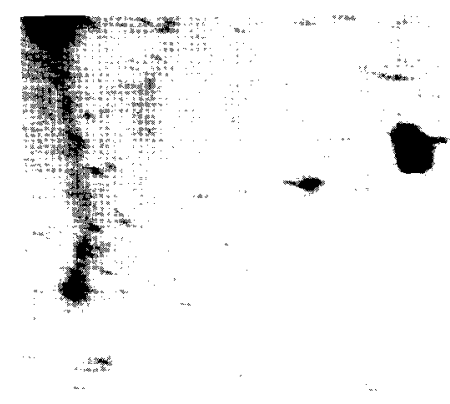

$\therefore$
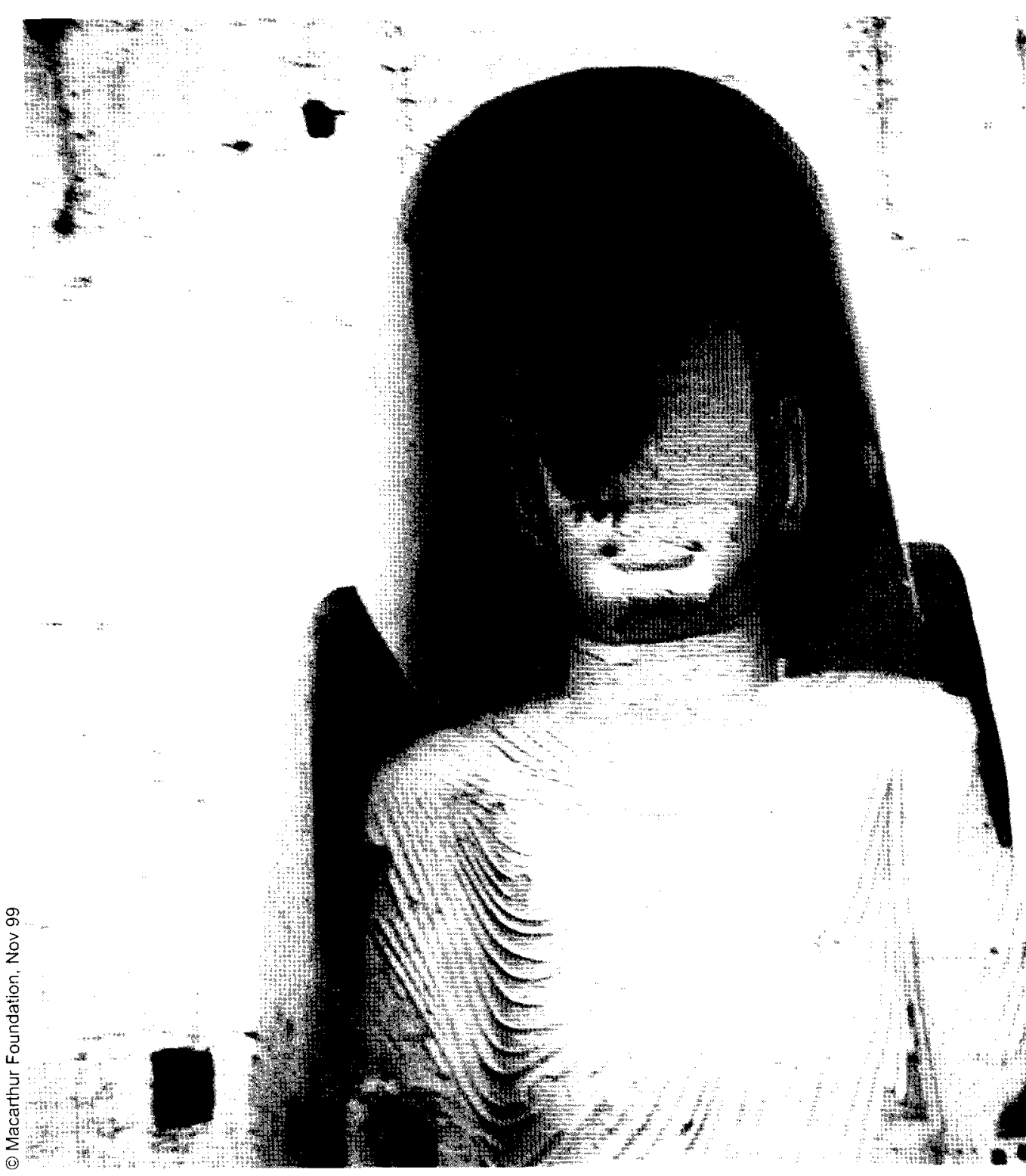


\section{SPACH LIBRARY SERIES}

$A$ s part of SPACH's advocacy efforts, the SPACH LIBRARY

SERIES was launched in 1998. Texts are published in English, Dari and Pashtu.

The first issue, "Status of Afghanistan's Cultural Heritage" by Nancy H Dupree, traces the beginning of cultural development in the area, explores existing problems and resources, and suggests steps which can be taken to contain the threats, emphasising individual and community action.
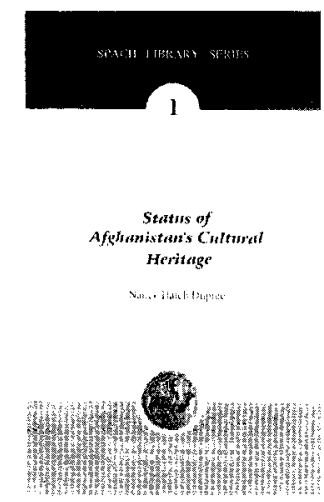

The second issue, "The Tomb of Hazarat-e-Ali: historical background \& recent events" by Abdul Ghafoor Safa and Mohammad Yunnus Sakayi, focuses on this important monument from the glorious Timurid Period.
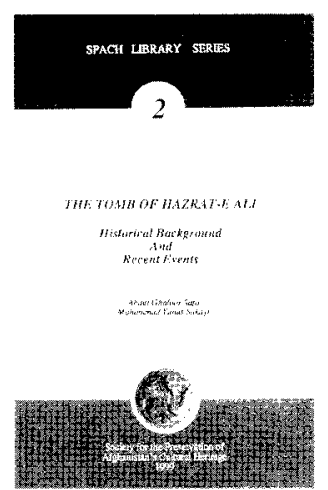

The third issue, "Minar-i-

Chakari: Afghanistan's lost and unsolved architectural riddle of great antiquity" by Chris M Dorn'eich, is devoted to the beautiful monument that collapsed in early April 1998.

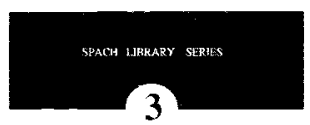

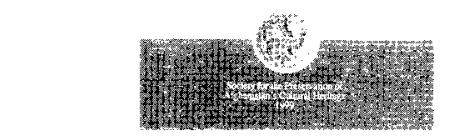

More issues are in preparation.
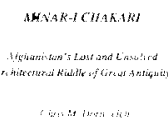

In April 2000, SPACH published Kateeba, a publication in Dari and Pashtu, which contains a summary of the first four SPACH NewsLetters which had not been translated so far. This publication has been initiated due to numerous requests by Afghans.

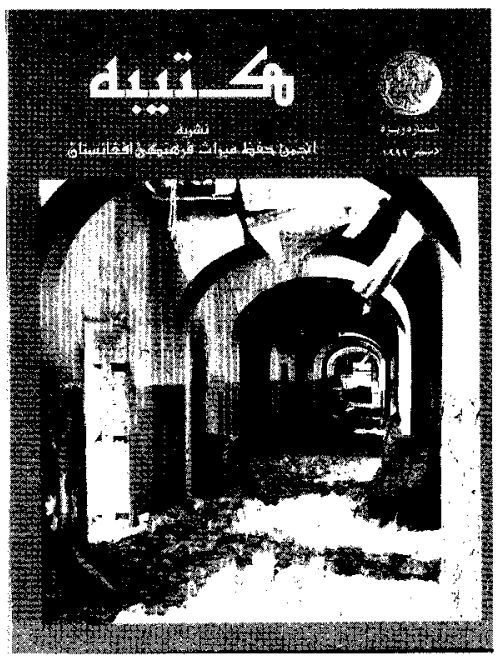




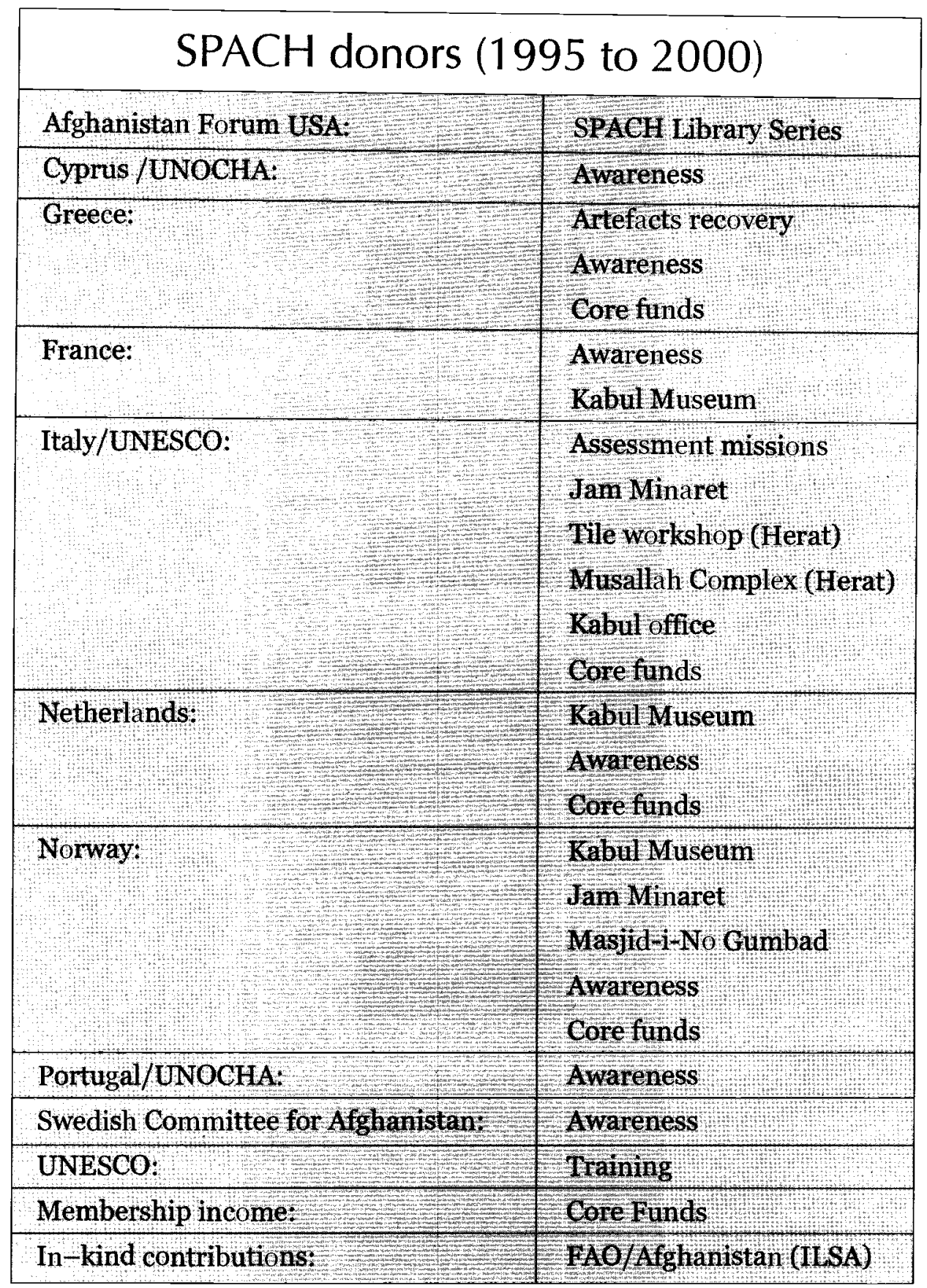

\section{SPACH REPRESENTATIVE IN KABUL}

At last SPACH has succeeded in finding a representative in Afghanistan. Robert Kluyver, who has relevant experience of working with NGOs in the region, started his challenging assignment in Kabul in March 2000. His task will be to develop a working relationship with the Ministry of Information and Culture and its officials, follow up on SPACH projects and train young talent in methods of recording and organising information on cultural heritage. He plans to devise a database of heritage sites and their current status.

To secure the continuity of his project for the next six months, an additional US\$25,000 are needed. 


\section{DECREES BY MULLAH OMAR \\ Issued by Mullah Mohammad Omar, Head of the Taliban Movement}

\section{A. "Concerning Protection of Cultural Heritage"}

All historical cultural heritage is regarded as an integral part of the heritage of Afghanistan and therefore belongs to Afghanistan, but naturally also to the international community. Any excavation or trading in cultural heritage objects is strongly forbidden and will be punished in accordance with the law.

\section{B. "Concerning Preservation of Historic Relics in Afghanistan"}

1 Historic and cultural relics of Afghanistan cover periods of several thousand years and concern culture, religion and beliefs also of civilisations of earlier periods up through the course of history. Afghanistan's cultural heritage is very rich and of central importance to the international arena. The government says that this heritage must be protected and preserved.

2 Excavation of historic places or sites is prohibited and must be stopped. Residential areas close to such sites must be kept from damaging the cultural heritage in any way.

3 The Ministry of Culture is responsible for giving the required instruction to all related departments and authorities in order to monitor and preserve the cultural heritage. The Ministry will seek assistance from military and religious leaders as well as those of the communities in carrying out this responsibility. Both the Ministry and the mentioned leaders have the responsibility to explain the value and importance of the heritage to the people. Should a serious incident happen, the police and other security forces shall be called in.

4 The Academy of Sciences of Afghanistan is responsible for authorising representatives of the Kabul Museum to inspect historical sites regularly and carry out professional inquiries.

5 Current legislation deals with illicit trading in historic objects in order to prevent such activity, defining heavy penalties for breaking the law. The Ministry of Interior and Customs, Ministry of Finance, Kabul Airport and the Intelligence Services share the responsibility of enforcing this legislation, in cooperation with the Ministry of Culture.

6 The famous Buddhist statues at Bamiyan were made before the event of Islam in Afghanistan, and are amongst the largest of their kind in Afghanistan and in the world. In Afghanistan there are no Buddhists to worship the statues. Since Islam came to Afghanistan until the present period the statues have not been damaged. The government regards the statues with serious respect and considers the position of their protection today to be the same as always. The government further considers the Bamiyan statues as an example of a potential major source of income for Afghanistan from international visitors. Further, international Buddhist communities recently issued a warning that in case the Bamiyan statues are damaged, then mosques will be damaged in their regions. The Muslims of the world are paying attention to this declaration. The Taliban government states that Bamiyan shall not be destroyed but protected.

7 The President of the Academy of Sciences of Afghanistan has the responsibility for the preservation of the Bamiyan statues. The Ministry is responsible for the overall preservation for all historic sites and objects and also for repairing and improving them for the future.

8 All military garrisons are instructed that historical sites cannot be used for military purposes, and are instructed to evacuate them immediately and move to locations isolated from historical sites. They shall also cooperate with the Ministry of Culture to safeguard historical sites and objects.

9 This decree issued by His Excellency concerning the preservation of historical relics is taken into consideration and is approved by the National Council. Therefore the Ministry of Culture shall work in accordance with it and enforce the decree. 


\section{HAS ANYONE SEEN THE DIPANKARA BAS RELIEF?}

\section{schist bas relief of the Dipankara \\ Jataka, from}

Shotorak, $2^{\text {nd }}-5^{\text {th }}$ century AD (height $83 \mathrm{~cm}$ ) is missing from the Kabul Museum.

${ }^{66}$ The ruins of the Buddhist monastery of Shotorak sit on a steep bluff overlooking the Panjsher River, about 40 miles north-east of Kabul. The crumbling remains of seven or eight other monasteries dot the landscape nearby, silently affirming the supposition that this was an important religious centre of Kapisa (Begram), the rich administrative and secular summer capital of the Kushans, two miles further north.

The monastery at Shotorak is said to have been built for a Chinese hostage prince taken by King Kanishka in the $2^{\text {nd }}$ century $\mathrm{AD}$. Although it was at its peak during the $2^{\text {nd }}$ to $4^{\text {th }}$ centuries, the Chinese pilgrim Hsuan-tsang reported nearly 300 priests still resident at Shotorak in the $7^{\text {th }}$ century. It was a large complex consisting of two spacious courtyards and ten stûpas faced with schist bas reliefs depicting a series of miraculous events in the life of the Buddha. Shotorak is unusually rich in schist reliefs, a rare material not readily found in the Afghan area. It would seem likely that this monastery was patronised by Kapisa's wealthier citizens who could afford to commission bas reliefs in this costly imported material. A number of unfinished reliefs and rough carvings indicated that the artwork of Shotorak was produced locally. Although belonging to a local school of Gandhara art, the later style of

Shotorak is heavier, more rigid and schematic. The Gandhara school served the cause of the Buddhist revival begun by Kanishka and its art forms spread as Buddhism was carried from India into Central Asia and eventually into China, changing to conform to the artistic ideals of the various regions it passed through. Most of the bas reliefs from Shotorak probably date from the $3^{\text {rd }}$ century, and represent the stylistic canons of the last phase of Gandhara art. Shotorak was excavated by French archaeologists (DAFA) in 1937."

Nancy H. Dupree
The National
Museum of
Afghanistan
Kabul 1974




\section{Membership Application \\ Membership fee: Rs 2,500 / US\$ 50 per calendar year \\ SPACH a/c 1020-604062-266 (US\$) \\ ANZ Grindlays Bank, P.O.Box 1004, Islamabad, Pakistan}

NAME:

ADDRESS:

COUNTRY:

Tel/Fax/e-mail:

NATIONALITY:

What aspect of Afghanistan's cultural heritage interests you?

Do you have information on Afghanistan's cultural heritage which may be valuable for the SPACH archive/network?

Persons who or institutions that should be informed about SPACH:

Other suggestions:

\section{SPACH}

c/o POB 2713

Islamabad, Pakistan

Members in Europe / US may wish to send their cheque / contribution to SPACH, c/o UNOCHA Geneva, 8-14, Avenue de la Paix (Room 400-16),

CH-1211 Geneva 10, Switzerland 

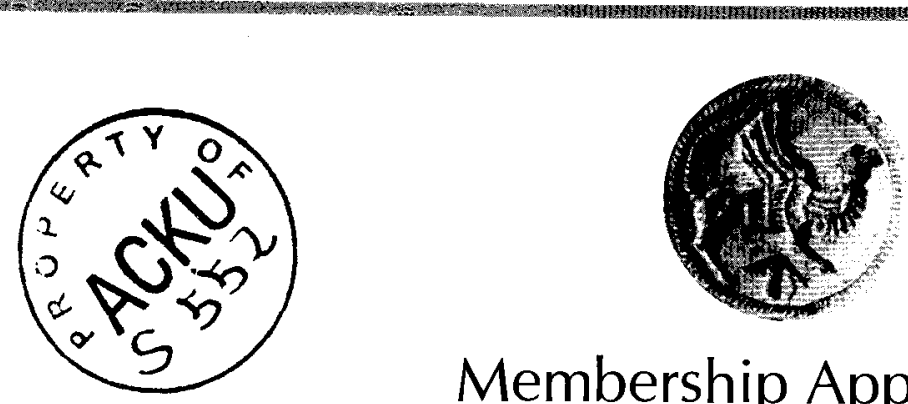

\section{Membership Application}

Form only for nationals of Afghanistan and Pakistan residing in Afghanistan and Pakistan

\section{Membership fee: $R$ s 400 per calendar year}

SPACH a/c 1020205508-001 (Pak Rupees)

ANZ Grindlays Bank, P.O.Box 1004, Islamabad, Pakistan

NAME:

ADDRESS:

COUNTRY:

Tel/Fax/e-mail:

NATIONALITY:

20 What aspect of Afghanistan's cultural heritage interests you?

Do you have information on Afghanistan's cultural heritage which may be valuable for the SPACH archive/network?

Persons who or institutions that should be informed about SPACH:

Other suggestions:

\section{SPACH}

c/o POB 2713

Islamabad, Pakistan 


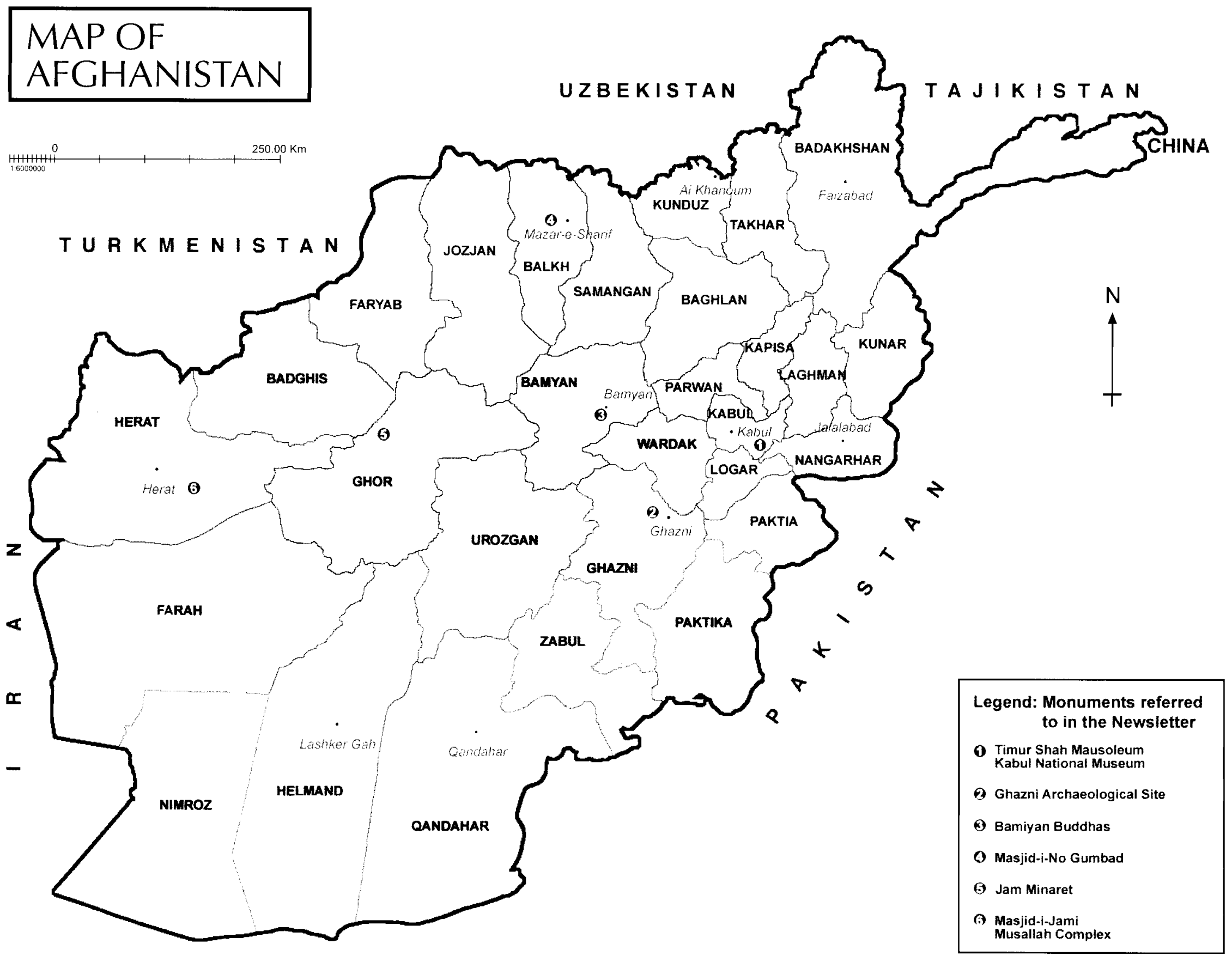

$N$ 
